\title{
Analisis Pada Penyelesaian Analisis Kompleks: Curiosity Attitude Mahasiswa
}

\author{
Aulia Sthephani $^{1 \varpi}$ dan Fitriana Yolanda ${ }^{2}$ \\ 1,2 Prodi Pendidikan Matematika, Universitas Islam Riau
}

\begin{tabular}{|c|c|}
\hline Info Artikel & Abstract \\
\hline $\begin{array}{l}\text { Sejarah Artikel: } \\
\text { Diterima } 8 \text { Mar } 2021 \\
\text { Direvisi } 26 \text { Mar } 2021 \\
\text { Disetujui } 17 \text { Apr } 2021\end{array}$ & $\begin{array}{l}\text { This research aims to describe and describe curiosity student. The indicators of curiosity in this } \\
\text { study are asking about information or problems given, reading sources outside the textbook about } \\
\text { material related to the lesson, the desire to learn, and the desire to solve problems. The subjects of } \\
\text { this research were students of the FKIP UIR mathematics education study program for the } \\
2019 / 2020 \text { academic year which consisted of } 60 \text { people. This research was conducted from April }\end{array}$ \\
\hline $\begin{array}{l}\text { Keywords: Analisis, } \\
\text { Curiosity Attitude, } \\
\text { Analisis Kompleks }\end{array}$ & $\begin{array}{l}2020 \text { to July 2020. The research method used was descriptive qualitative. Retrieval of data using a } \\
\text { curiosity questionnaire instrument at the completion of the complex analysis that has been } \\
\text { developed by the researcher. The data analysis technique used was qualitative questionnaire data } \\
\text { analysis. The results of data analysis show that overall the curiosity is students'classified as "good" }\end{array}$ \\
\hline $\begin{array}{l}\text { Paper type: } \\
\text { Research paper }\end{array}$ & $\begin{array}{l}\text { with an average questionnaire score of } 75.19 \% \text {, this indicates that there is curiosity of students } \\
\text { towards solving complex analyzes, but it still needs to be improved through learning that can } \\
\text { increase student curiosity. }\end{array}$ \\
\hline
\end{tabular}

\begin{abstract}
Abstrak
Penelitian ini bertujuan untuk memaparkan dan mendeskripsikan rasa ingin tahu (curiosity) mahasiswa. Indikator-indikator rasa ingin tahu pada penelitian ini adalah bertanya tentang informasi atau masalah yang diberikan, membaca sumber diluar buku teks tentang materi yang terkait dengan pelajaran, keinginan untuk belajar, dan keinginan untuk memecahkan masalah. Subjek penelitian ini adalah mahasiswa program studi pendidikan matematika FKIP UIR tahun ajaran 2019/2020 yang terdiri dari 60 orang. Penelitian ini dilaksanakan mulai dari bulan April 2020 sampai Juli 2020. Metode penelitian yang digunakan adalah deskriptif kualitatif. Pengambilan data menggunakan instrumen angket rasa ingin tahu (curiosity) pada penyelesaian analisis kompleks yang telah dikembangkan oleh peneliti. Teknik analisis data yang digunakan adalah analisis data angket secara kualitatif. Hasil analisis data menunjukkan bahwa secara keseluruhan rasa ingin tahu (curiosity) mahasiswa tergolong "baik" dengan nilai rata-rata angket sebesar 75,19\%, hal ini menunjukkan bahwa adanya rasa ingin tahu (curiosity) mahasiswa terhadap penyelesaian analisis kompleks, namun masih perlu ditingkatkan lagi melalui pembelajaran yang dapat meningkatkan rasa ingin tahu mahasiswa.
\end{abstract}

(C) 2021 Universitas Muria Kudus

\begin{tabular}{lr}
\hline đAlamat korespondensi: & p-ISSN 2615-4196 \\
Program Studi Pendidikan Matematika & e-ISSN 2615-4072 \\
Fakultas Keguruan dan Ilmu Pendidikan Universitas Muria Kudus & \\
Kampus UMK Gondangmanis, Bae Kudus Gd. L. 1t I PO. BOX 53 Kudus & \\
Tlp (0291) 438229 ex.147 Fax. (0291) 437198 & \\
E-mail: sthephania@edu.uir.ac.id &
\end{tabular}


Aulia Sthephani dan Fitriana Yolanda

Anargya: Jurnal Pendidikan Matematika, Vol. 4 No.1, April 2021

https://dx.doi.org/10.24176/anargya.v4i1.6007

\section{PENDAHULUAN}

Sikap rasa ingin tahu sangat diperlukan pada proses pembelajaran di kelas untuk mendorong minat mahasiswa mempelajari dan mendalami materi yang dipelajari dengan adanya rasa ingin tahu dapat membuat mahasiswa menggali informasi yang tidak diketahuinya dari kegiatan belajar mengajar. Sesuai dengan pernyataan Suriasumantri (2007) berpendapat bahwa rasa untuk mempelajari suatu hal yang baru yang harus diketahui agar dapat menjawab ketidaktahuannya merupakan hal yang membuat rasa ingin tahu itu timbul karena rasa ingin tahulah yang memulai sebuah pengetahuan. Rasa ingin tahu itu sendiri diartikan sebagai adanya keinginan untuk memperoleh pengetahuan baru dari kegiatan belajar (Mardhiyana, 2017).

Proses revolusi yang ada pada diri manusia paling besar terhadap dampak dari kesuksesan dan peningkatan dalam hidupnya adalah rasa ingin tahu yang luas, karena dengan rasa ingin tahu yang besar tersebut mampu membuat hidup mereka kedepan memiliki arti terutama dari segi perkembangan kemampuan berpikir dan ilmu pengetahuan meningkat luas. Rasa ingin tahu dapat membuat manusia untuk berkembang didalam kehidupannya dengan cara terus belajar sehingga dengan rasa ingin tahu tersebut dapat membuat manusia memperoleh suatu keyakinan akan kebenaran terhadap suatu hal baru (Nugroho, 2019). Hal ini juga sejalan dengan pendapat yang mengatakan bahwa rasa ingin tahu dapat membuat manusia termotivasi untuk mencari tahu tentang hal-hal baru sehingga dapat menambah ilmu pengetahuan dan pengalaman belajar yang baru. Peradaban baru manusia dalam dunia pembangunan saat ini juga terbentuk dari dampak besarnya pola pikir yang baik dan maksimal sehingga kemajuan pembangunan terlihat lebih jelas (Brockman, 2013).

Karakter rasa ingin tahu sangat penting dalam proses pembelajaran, seperti yang diungkapkan oleh Ardiyanto (2013) bahwa rasa ingin tahu dapat membuat mahasiswa tidak merasa bosan saat proses belajar mengajar karena rasa ingin tahu meningkatkan motivasi mahasiswa untuk menggali dan mempelajari lebih mendalam sehingga timbul rasa puas dalam dirinya, melalui rasa ingin tahu ini juga mahasiswa dibuat menjadi pemikir yang aktif dan pengamat yang aktif. Mahasiswa harus memiliki ilustrasi keingintahuan seperti mengapa dan bagaimana (Inan, Watson, Whitcomb \& Yigit, 2018). Kegiatan belajar yang menjadikan ingin tahu tersebut dapat mendorong mahasiswa untuk terus belajar dan menggali informasi yang lebih dalam lagi.

Salah satu ciri mahasiswa yang memiliki rasa ingin tahu yang tinggi adalah mahasiswa yang sering mengajukan pertanyaan untuk mengetahui informasi mengenai materi yang dipelajari (Silberman dalam Salirawati, 2012). Mengenal rasa ingin tahu menjadi perhatian lebih dalam setiap keinginan (Watson, 2018). Oleh karena itu, salah satu cara yang dapat digunakan untuk mengembangkan rasa ingin tahu adalah dengan mengajukan pertanyaan-pertanyaan yang menantang pada saat proses belajar mengajar sehingga dapat membuat mahasiswa penasaran dian ingin mencari tahu jawaban dari pertanyaan yang diberikan.

Mata kuliah analisis kompleks adalah matakuliah wajib yang harus diampu oleh mahasiswa pada semester 6. Untuk mengambil matakuliah ini, mahasiswa sudah terlebih dahulu mendapatkan bekal pada matakuliah kalkulus, pengantar dasar matematika dan analisis real. Pada dasarnya, nilai akhir untuk matakuliah yang telah diampu tadi akan berbanding lurus dengan nilai akhir matakuliah analisis kompleks berdasarkan penelitian sebelumnya yang dilakukan peneliti tentang kemampuan berpikir kreatif mahasiswa pada penyelesaian soal analisis kompleks yang masih rendah (suripah \& sthephani, 2018), oleh karena itu peneliti ingin mengetahui sejauh mana rasa ingin tahu, mahasiswa terhadap matakuliah analisis kompleks ini.

Untuk itu perlu mengembangkan rasa ingin tahu (curiosity) mahasiswa dalam proses belajar mengajar. Salah satu mata kuliah yang dipelajari mahasiswa pendidikan matematika adalah analisis kompleks. Mata kuliah analisis kompleks merupakan salah satu mata kuliah yang ada di jenjang Perguruan Tinggi. Materi dalam mata kuliah analisis kompleks meliputi operasi bilangan kompleks, fungsi kompleks, turunan kompleks dan integral kompleks. Disamping diperlukan pemahaman yang baik, sikap ilmiah rasa ingin tahu juga dapat terbentuk dari menemukan penyelesaian materi analisis kompleks. Oleh karena itu, peneliti ingin mengetahui rasa ingin tahu mahasiswa terhadap penyelesaian masalah analisis kompleks.

Indikator rasa ingin tahu (curiosity) adalah sebagai berikut: 1) bertanya tentang informasi atau masalah yang diberikan; 2) berkeinginan mengetahui hal secara rinci; 3) antusias/semangat dalam belajar; 4) mencari informasi dari berbagai sumber; 5) mencoba alternative dari pemecahan masalah (Zetriuslita, 2016). Pendapat lain juga mengkategorikan indikator rasa ingin tahu (curiosity) yaitu: 1) Bertanya atau membaca sumber di luar buku teks tentang materi yang terkait dengan pelajaran; 2) Membaca atau mendiskusikan gejala alam yang baru terjadi; 3) Bertanya tentang beberapa peristiwa alam, sosial. Budaya, ekonomi, politik, teknologi yang baru didengar; 4) Bertanya tentang sesuatu yang terkait dengan materi pelajaran 
di luar bahasan di kelas (Asmoro \& Mukti, 2019). Menurut Latifah \& Widjajanti (2017), indikator rasa ingin tahu dikategorikan menjadi: Indikator: 1) Keinginan untuk belajar; 2) Keinginan untuk menyelidiki; 3) Keinginan untuk mendapatkan informasi atau pengetahuan yang baru; 4) Keinginan untuk memecahkan masalah. (Latifah \& Widjajanti, 2017).

Berdasarkan definisi yang diberikan dan ciri-ciri dari rasa ingin tahu (curiosity) yang telah dijabarkan di atas maka indikator rasa ingin tahu yang digunakan untuk penelitian ini adalah:

1) Bertanya tentang informasi atau masalah yang diberikan

2) Membaca sumber di luar buku teks tentang materi yang terkait dengan pelajaran

3) Keinginan untuk belajar

4) Keinginan untuk memecahkan masalah.

\section{METODE PENELITIAN}

Jenis penelitian ini adalah penelitian deskriptif kualitatif yang menjelaskan tentang rasa ingin tahu (curiosity) mahasiswa pada penyelesaian analisis kompleks. Subjek dari penelitian ini adalah mahasiswa program studi pendidikan matematika FKIP UIR tahun ajaran 2019/2020 yang berjumlah 60 orang. Penelitian ini dilaksanakan mulai dari bulan April 2020 sampai Juli 2020. Instrumen pada penelitian ini adalah kuesioner berisi pernyataanpernyataan yang menggambarkan rasa ingin tahu (curiosity) mahasiswa pada penyelesaian analisis kompleks. Teknik pengumpulan data mengunakan angket serta di analisis secara kualitatif. Berikut ini kisi-kisi dan kuesioner sebagai instrumen penelitian yang digunakan:

\begin{tabular}{|l|l|c|c|}
\hline \multirow{2}{*}{ No. } & \multicolumn{1}{|c|}{ Indikator } & \multicolumn{2}{|c|}{ Nomor Butir } \\
\cline { 3 - 4 } 1. & $\begin{array}{l}\text { Bertanya tentang informasi } \\
\text { atau masalah yang diberikan }\end{array}$ & $1,5,26,37$ & $16,21,38$ \\
\hline 2. & $\begin{array}{l}\text { Membaca sumber di luar } \\
\text { buku teks tentang materi } \\
\text { yang terkait dengan } \\
\text { pelajaran }\end{array}$ & $2,8,27,35,36,39$ & 18,31 \\
\hline 3. & Keinginan untuk belajar & $3,4,11,12,24,32$ & $13,17,23,28,29,30$ \\
\hline 4. & $\begin{array}{l}\text { Keinginan untuk } \\
\text { memecahkan masalah }\end{array}$ & $\begin{array}{l}6,7,9,10,14,15,25,33, \\
19,20,22\end{array}$ \\
\hline
\end{tabular}

Gambar 1. Kisi-kisi Kuesioner
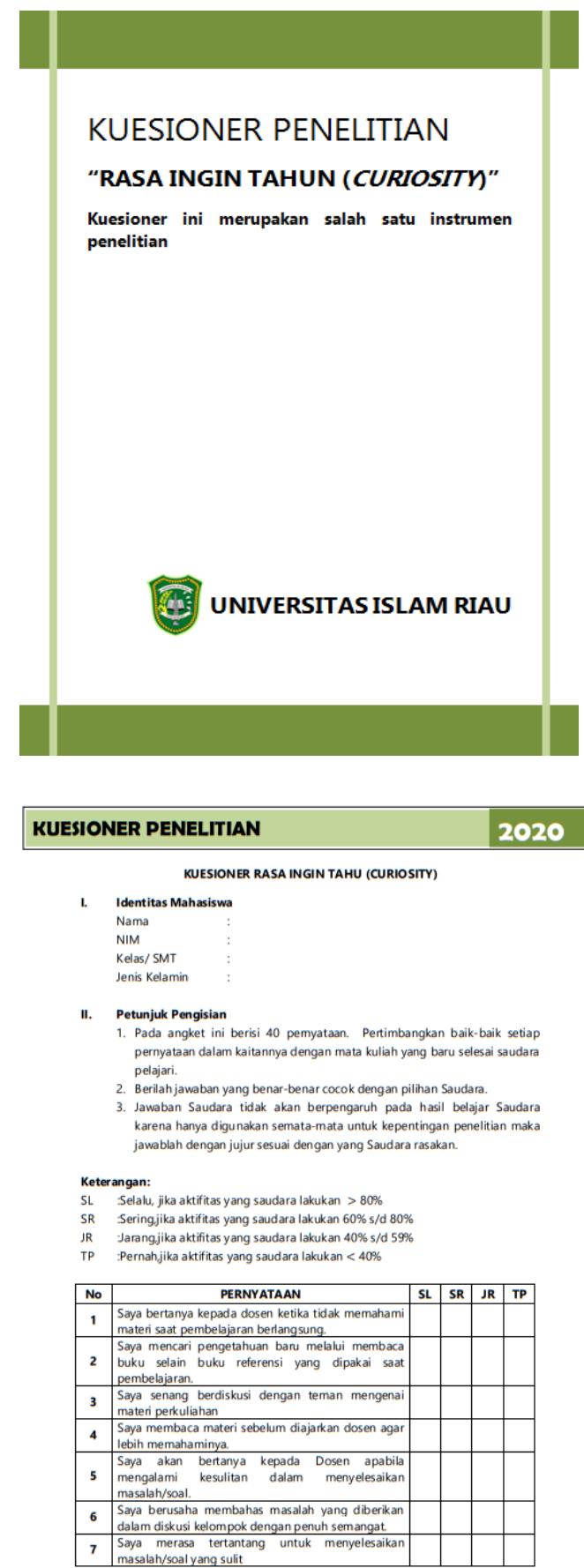


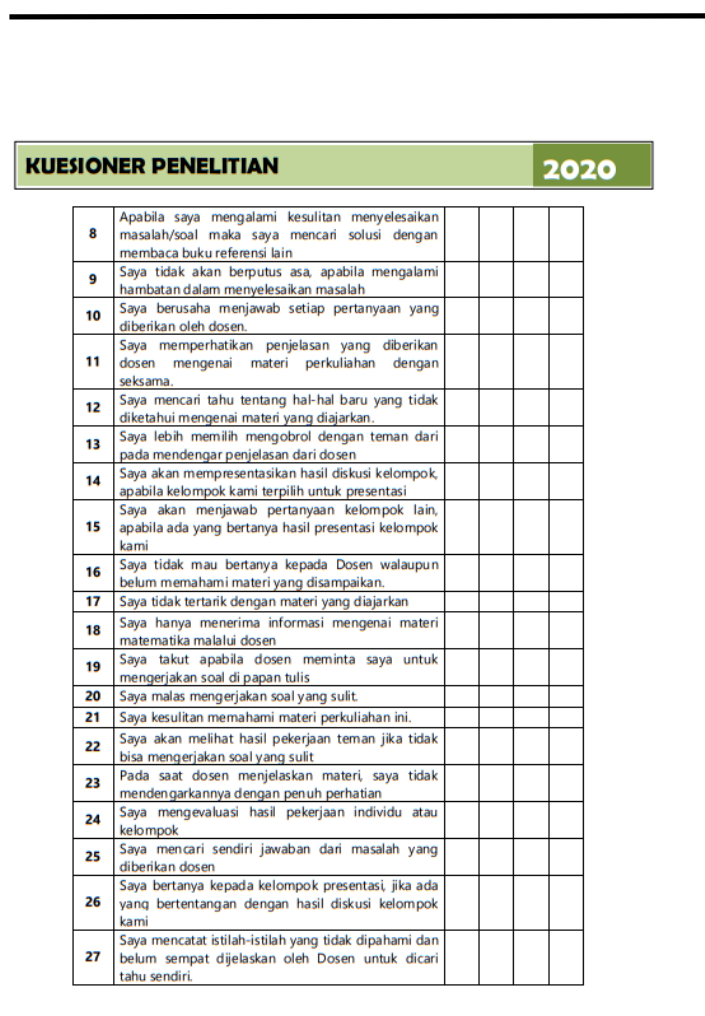

KUESIONER PENELITIAN 2020

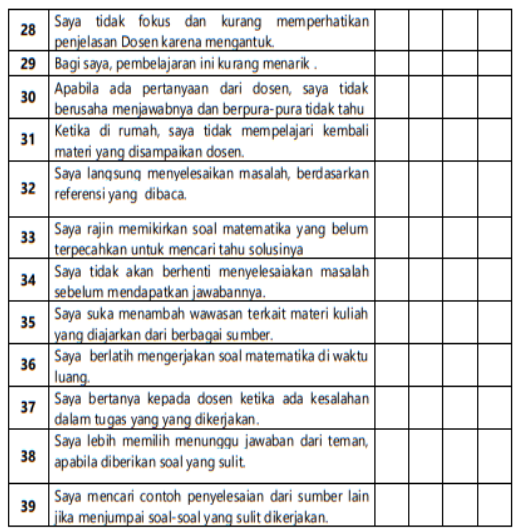

TERIMA KASIH

\section{Gambar 2. Instrumen Penelitian}

Rumus yang digunakan untuk menganalisis data penelitian yang telah diperoleh dari angket rasa ingin tahu (curiosity) adalah sebagai berikut:

$\mathrm{P}=(\mathrm{F} / \mathrm{N}) * 100 \%$, Ket: $\mathrm{P}$ : persentase, $\mathrm{F}$ : frekuensi dari setiap alternative jawaban yang dipilih dari responden, N: jumlah sampel ( Rukajat, 2018)

Setelah memperoleh nilai persentase angket rasa ingin tahu (curiosity), maka untuk mengetahui kriterianya akan dilihat berdasarkan tabel berikut:

Tabel 1. Analisis Data Angket

Interval Skor

Kriteria

\begin{tabular}{cc}
\hline Interval Skor & Kriteria \\
\hline$X>84 \%$ & Sangat Baik \\
$69 \%<X \leq 84 \%$ & Baik \\
$54 \%<X \leq 69 \%$ & Sedang \\
$39 \%<X \leq 54 \%$ & Rendah \\
$\leq 39 \%$ & Sangat Rendah
\end{tabular}

Modifikasi Riduwan \& Sunarto (2009)

\section{HASIL DAN PEMBAHASAN}

Penelitian ini bertujuan untuk mengetahui seberapa besar rasa ingin tahu mahasiswa terhadap penyelesaian analisis kompleks. Instrumen curiosity yang telah dikembangkan, selanjutnya diujicobakan kepada para responden yang berjumlah 60 orang mahasiswa. Adapun hasil olahan data angket curiosity, diuraikan sebagai berikut:

Tabel 2. Analisis Persentase Data Angket

\begin{tabular}{ccc}
\hline$\sum \boldsymbol{F}$ & $\sum \boldsymbol{P}$ & $\mathbf{P}$ \\
7038 & 9360 & $75,19 \%$
\end{tabular}

Keterangan:

$P$ : Persentase

F: Frekuensi dari setiap alternatif jawaban yang

dipilih oleh responden

N: Jumlah Sampel

Berdasarkan Tabel.2 tersebut, dapat dilihat bahwa secara keseluruhan mahasiswa memiliki sikap rasa ingin tahu (curiosity) dengan kategori "baik". Rasa ingin tahu merupakan keinginan untuk mencari tahu suatu informasi tentang sesuatu yang ingin dipelajari dengan cara belajar (Mardhiyana, 2017) Ini dapat dilihat dari nilai rata-rata total yang diperoleh yaitu $75,19 \%$.

Tabel 3. Analisis Data Angket Setiap Indikator

\begin{tabular}{cccc}
\hline No. & Indikator & Persentase(\%) & Kategori \\
\hline 1. & Indikator 1 & 72.80 & Baik \\
\hline 2. & Indikator 2 & 73.91 & Baik \\
\hline 3. & Indikator 3 & 80.31 & Baik \\
\hline 4. & Indikator 4 & 72.33 & Baik \\
\hline
\end{tabular}

Keterangan:

Indikator 1 :Bertanya tentang informasi atau masalah yang diberikan

Indikator 2 :Membaca sumber di luar buku teks tentang materi yang terkait dengan pelajaran 
Indikator 3 :Keinginan untuk belajar

Indikator 4 :Keinginan untuk memecahkan masalah

Berdasarkan Tabel.3 di atas, setiap indikator angket yang dijadikan acuan dalam pengambilan data angket, diketahui bahwa indikator 1 memperoleh nilai rata-rata $72,80 \%$ dengan kategori "baik", indikator 2 memperoleh rata-rata 73,91\% dengan kategori "baik", indikator 3 memperoleh rata-rata $80,31 \%$ dengan kategori "baik" dan indikator 4 memperoleh rata-rata $72,33 \%$ dengan kategori "baik".

Pada indikator 3 yaitu "Keinginan untuk belajar" merupakan satu indikator yang nilainya paling tinggi dari tiga indikator lainnya, dengan perolehan nilai rata-ratanya $80,31 \%$. Ini menunjukkan bahwa untuk indikator 3, sikap ingin tahu (curiosity) mahasiswa tergolong "baik". Hal ini sesuai dengan pendapat Listriania \& Aini (2019) Rasa ingin tahu dapat memberikan dorongan kepada seseorang untuk mengetahui segala sesuatu yang membuat penasaran, hal ini dapat memancing keinginan seseorang tersebut untuk terus mencari tahu dan belajar baik secara langsung atau tidak langsung.

Untuk indikator 2 yaitu "Membaca sumber di luar buku teks tentang materi yang terkait dengan pelajaran" memperoleh nilai rata-rata $73,91 \%$ dengan kategori "baik" hal ini sesuai dengan pendapat Fadilah \& Kartini (2019) Rasa ingin tahu senantiasa akan memotivasi diri untuk terus mencari dan mengetahui hal-hal yang baru sehingga akan memperbanyak ilmu pengetahuan dan pengalaman dalam kegiatan belajar.

Selanjutnya, indikator 1 "Bertanya tentang informasi atau masalah yang diberikan" memperoleh nilai rata-rata $72,80 \%$ dengan kategori "baik". Sedangkan untuk indikator 4 "Keinginan untuk memecahkan masalah" memperoleh nilai rata-rata $72,33 \%$ dengan kategori "baik". Fadilah \& Kartini (2019) menyatakan rasa penasaran dan ingin tahu biasa kita alami jika ada suatu persoalan yang belum terselesaikan.

Berdasarkan hasil analisis untuk setiap indikator diatas, secara keseluruhan sikap rasa ingin tahu (curiosity) mahasiswa masuk pada kategori "baik" namun masih perlu ditingkatkan lagi melalui pembelajaran yang dapat merangsang dan meningkatkan rasa ingin tahu mahasiswa karena menurut Zetriuslita (2016) Pada dasarnya siapapun dan terhadap apapun ada rasa ingin tahu. Namum yang perlu digarisbawahi adalah seberapa besar rasa ingin tahu yang muncul pada masingmasing diri peserta didik.

\section{KESIMPULAN}

Berdasarkan hasil analisis data dan pembahasan, maka dapat disimpulkan bahwa secara keseluruhan rasa ingin tahu (curiosity) mahasiswa terhadap penyelesaian analisis kompleks tergolong "baik". Namun untuk indikator 4 yaitu "Keinginan untuk memecahkan masalah" perlu diasah dan ditingkatkan lagi.

\section{DAFTAR PUSTAKA}

Ardiyanto, D. 2013. Pembelajaran Dengan Pendekatan Kontekstual Berbantuan Hands on Problem Solving untuk Meningkatkan Rasa Ingin Tahu dan Prestasi Belajar Siswa. Prosiding Seminar Nasional Matematika dan Pendidikan Matematika Tahun 2013. 157184.

Asmoro, B. P., \& Mukti, F. D. 2019. Peningkatan Rasa Ingin Tahu Ilmu Pengetahuan Alam Melalui Model Contextual Teaching and Learning Pada Siswa Kelas Va Sekolah Dasar Negeri Karangroto 02. Abdau: Jurnal Pendidikan Madrasah Ibtidaiyah, 2(1), 115142.

Brockman, J. 2013. Thinking: The New Science of Decision-Making, Problem-Solving, and Prediction in Life and Markets. Harper Collins.

Fadilah, I., \& Kartini, S. T. 2019. Indentifikasi Sikap Rasa Ingin Tahu Siswa Terhadap Pembelajaran Fisika di Man 1 Batanghari. Sukma: Jurnal Pendidikan, 3(2), 217-231..

Latifah, U. H., \& Widjajanti, D. B. 2017. Pengembangan bahan ajar statistika dan peluang berbasis multiple intelligences berorientasi pada prestasi, pemecahan masalah, dan rasa ingin tahu. Jurnal Riset Pendidikan Matematika, 4(2), 176.

Listriania, N. D., \& Aini, K. N. 2019. Pengaruh Pembelajaran Kontekstual Berbantuan Hands n Activity terhadap Kemampuan Pemecahan Masalah Matematik dan Rasa Ingin Tahu Siswa. Jurnal Inovasi Pendidikan Dan Pembelajaran Matematika, 5(1), 50-61.

Mardhiyana, D. 2017. Upaya Meningkatkan Rasa Ingin Tahu Mahasiswa Melalui Penerapan Pembelajaran Berbasis Proyek Pada Mata Kuliah Evaluasi Proses Dan Hasil Pembelajaran Matematika. Delta: Jurnal Ilmiah Pendidikan Matematika, 5(1), 1.

Nugroho, I. 2019. Memahami Rasa Ingin Tahu Remaja Ditinjau Berdasarkan Jenis Kelamin. Jurnal Bimbingan Dan Konseling ArRahman, 5(1), 1-5.

Riduwan, \& Sunarto. 2009. Pengantar Statistika.Bandung: Alfabeta.

Rukajat, A. 2018. Pendekatan penelitian 
kuantitatif: quantitative research approach. Deepublish.

Salirawati, D. 2012. Percaya Diri, Keingintahuan, Dan Berjiwa Wirausaha: Tiga Karakter Penting Bagi Peserta Didik. Jurnal Pendidikan Karakter, 0(2), 213-224.

Suriasumantri, J. S. 2007. Filsafat ilmu. Jakarta: Pustaka Sinar Harapan..

Suripah, S., \& Sthephani, A. 2017. Kemampuan berpikir kreatif matematis mahasiswa dalam menyelesaikan akar pangkat persamaan kompleks berdasarkan tingkat kemampuan akademik. Pythagoras: Jurnal Pendidikan Matematika, 12(2), 149-160.

Watson, L., Inan, I., Whitcomb, D., \& Yigit, S. 2018. Educating for curiosity. The moral psychology of curiosity, 293-309.

Watson, L. 2018. Curiosity and inquisitiveness. The Routledge Handbook of Virtue Epistemology,155-a.

Zetriuslita, Z. 2016. Profil Sikap Ilmiah Rasa Ingin Tahu (Curiosity) Matematis Mahasiswa. Jurnal Ilmu Pendidikan (JIP) STKIP Kusuma Negara, 8(1), 41-46.. 